\title{
Irodalmi matézis
}

\author{
Büky László \\ SZTE Magyar Nyelvészeti Tanszék
}

\begin{abstract}
Összefoglaló
Az irodalmi művekben ritka a matematikai vagy logikai fogalmak használata. Ismeretük műveltség vagy műveletlenség jelzésére, valamilyen szimbolikusság megjelenítésére alkalmas. Mint nyelvi elemek nagy hírértékűek, erős lehet stiláris hatásuk, amelyet jelöléseik $(+,-, x, \sqrt{ }, \infty$ stb.) írásképe erősít.

Kulcsszavak: Csokonai Vitéz Mihály, Arany János, Karinthy Frigyes, Weöres Sándor, Radnóti Miklós, Marno János
\end{abstract}

Ritkán kerül szépirodalmi szövegmüvekben az olvasó szeme elé valamilyen matematikai (logikai) fogalom vagy az azt jelentő szó, esetleg jel. Az efféle esetekben többnyire a matematika mint olyan érthetetlensége említődik.

A matematikai ismeretek hiányának említését különböző célra használhatja az író, például műve szereplőjének az e szempont szerinti műveletlenségét jelezni. Az ilyen műveltség híjába lévőt már maga a matematika szó (vagy valamelyik derivátuma) is elkápráztat(hat)ja.

A Csokonai Vitéz Mihály egyik vígjátékában szereplő kirurgus, a beszélő nevű Kuruzs, aki elmondja magáról, hogy chiromanista, Lipittlotty tenyerét vizsgálva kijelenti: „[...] ez a' hosszan nyuló huzás mi volna egyéb egy kötélnél, ez pedig mathematice is egy valóságos akasztófa" (Csokonai 1978: 199).

Arany János Hatvani címü költeményében Debrecen híres tanárának magyarázata révén „[s]ok görbe szám s ABRACADABRA | Firkáitól hemzseg a tábla” (Arany 1966a: 301). A szám fönév és főként az ABRACADABRA jelzi a kívülálló számára az érthetetlen ábrázolatokat. Az abrakadabra 'zagyvaság, értelmetlen (beszéd)' jelentése ezt jól igazolja, Id. TESz., Nszt.

A Matkó István és Sámbár Mátyás XVII. századi vitairataiból elhíresült szólásnak - $X$ ut tök 'buta, mint a tök' - $x$ jele is kelthet matematikai képzettársításokat. A kifejezés szerepel Csokonai egyik tanulmányában, az Elôbeszéd [A' Tavaszhoz] szövegében: „Ama Finnyáskodó pedig olvassa meg a’ Heltai, Tinódi, Valkai [...], és egyebek velős Magyar Irásit; sőt holmi Bányász Csákányt, Sopronyi Veres Tikmonyat, $X$ ut Tököt, és több efféle korpá[j]ú Grapsákat se hagyjon megtekinthetetlen [...]" (Csokonai 2002: 37). A szólást Arany János is fölhasználja a némi ironikussággal: „Ott Calepinus jő, a Bábel tornya utána; | Hátrább $X$ ut Tök, meg a többi piszoktele firkák" (Arany 1966b: 1376). Móricz Zsigmond ugyancsak alkalmazza ezt a régi mondást: „Tudósokat nevelnek. Tudományos papnevelés. Kérem, a papnak nem baj, ha olyan szamár mint az iksz, csak szerető és gyöngéd lelkü egyházatya legyen" (Móricz 1962: 258). 
Az említett matematikai képzeteket az $x$ válthatja ki: lévén az ismeretlen jele. Esetleg a 'butaság' értelmet jelenhetné az $x$, minthogy az 'ismeretlen'-t jelöli René Descartes (1596-1650) Értekezések a módszerról című művének geometriai tárgyú függeléke nyomán. Valószínübb, hogy a katolikus és protestáns hitvitázók nem ennek, hanem Arany János kifejezésével a „piszoktele firkák” küllemre, írásképre is zagyvaságára mint a szellemi zavarosságra, a butaságra céloznak vele. Trócsányi Zoltán bár alaposan utánajárt a kifejezés eredetének és használatának, az $x$-ről fölteszi, hogy „[...] lehet a mennyiségtannak az ismeretlent jelölő betűje, lehet a kártyajáték tizese, és még valami, a miről később lesz szó” (Trócsányi 1918: 88). Később azonban nem ír többet az $x$-ről.

Arany János a Bolond Istókban írja: „Oh, hányszor elmereng a tiszta mennybe, | Hol a tejút és többi napkörök | Egy-egy láncszem tovább, a végtelenbe, | Hol milliárd nap és bolygó görög; | A Sirius-hossz, ily távollal szembe, | Már semmi, hát még ez a földi rög!... | De iskolában rettenté a sok $\mid A+b$, nagy $\sqrt{ }$ a dült $\infty$-asok"; továbbá: „»Folytassa Istók! « »X, emelve á-ra«... | Szegény myopsunk csak ötölt-hatolt; -” (Arany János 1966c: 1576, 1577). Istók rövidlátó volta miatt kerül ugyanolyan megítélésbe, mint azok, akik nem értik a matematikát. (Az Arany által is használt jelölések közül az $A$ és $b$ ugyancsak Descartes-tól ered.)

Marno János egyik verskötetének címében és egyik versében is szerepel a gyökjel: „Nincsen líra $\sqrt{ }$ nélkül” és: „nincsen líra tenger líra $\sqrt{ } \mid$ hengeren, mint a bimbók, kiáll | egypár hűvös élményburok [...]” (1999: 69). Marno költészetéről írva Radics Viktória azt mondja, hogy a költő számára az „,...] öntest, a Leib az a hely és médium”, amellyel ki tudja fejezni „a versképző és gondolatokat termelő folyamatot”, továbbá „[e]z a Leib az a hely akár odatehető a »Nincsen líra $\sqrt{ }$ nélkül« hiányjelébe. Tölcsérbe, homokórájába" (Radics 2019: 83). A $\sqrt{ }$ rajzolat a klasszikus nyomdai korrektúrában valóban az egyik lehetséges hiányjel, sőt az előbbi irodalmi elemző szerint mint grafikai értelmezésű metaforával 'tölcsér', illetőleg 'homokóra'. (Utóbbi élénk képzelőerőről vall.) A (nyomdai) korrektúrák gyakorlatában a jel használata általános volt, jobbra-balra húzott fölső vonallal vagy vonalakkal is, Id. Timkó (1972: 334). Ezt a korrektúrajelet szabvánnyá tették, utolsó módosítása: MSZ 3491-1989. 2: 3.1.4. Kiadásakor megegyezett az ISO 5776:1983 nemzetközi szabvánnyal, ennek jelenleg érvényes kiadása: az ISO 5776:2016, amelyet érdeklődés hiányában nem vezettek be magyar szabványként. ${ }^{1}$ (2003. november 1-én a magyar szabványt visszavonták, az ilyen szabványokat azonban lehet és szabad alkalmazni, ha abban az érintettek megegyeznek.) A Marno-verseskötet címe az szegedi tudományegyetem könyvtára online katalógusában „Nincsen líra [gyökjel] nélkül” leírással, az Országos Széchényi Könyvtáréban „Nincsen líra \# nélkül” található mutatván a jel értelmezésében és leírásában való zavart.

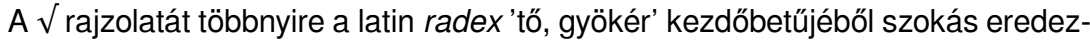
tetni. Ez a jel először nyomtatásban a felső vízszintes vonal nélkül jelent meg 1525ben, Christoph Rudolff német matematikus által írt Die Coss-ban. A végtelent jelentő $\infty$ John Wallis (1616-1703) nevéhez köthető. A rajzolat egyezhet Domenico Cassini (1625-1712) nevéhez kapcsolt negyedrendű algebrai görbével, lemniszkátával. A + és - müveleti jelek Johannes Widmann (1427-1498 u.) lipcsei egyetemi

${ }^{1}$ A szabványokra vonatkozó adatokat Haba József Ottó főosztályvezetőnek (Magyar Szabványügyi Testület) köszönöm. 
tanárnak már nyomtatott könyvében is szerepel, kézírásos munkákban előbb; később is, 1514-ben Giel Ander Hoecke munkájában. Az alább szóba jövő egyenlőségjelet (=) Robert Recorde kezdte használni 1557-ben.

Az eddigi irodalmi művekhez képest nem az érthetetlenség vagy a matematikai műveletlenség okán, hanem valamilyen stílushatás elérése céljából jelenik meg számtani vonatkozás. Például a versében megjelenő számtani műveletnek magától értetődő természetes voltát tételezi föl Radnóti Miklós: „[...] s folyton veszélyben, bajban élő | vad férfiak fegyvert s hatalmat érő | nyugalma nyugtat s mint egy hűvös hullám: | a 2 × 2 józansága hull rám" (Radnóti 1959: 263). A 2 × 2 józansága metaforában a józanság jelentése elfogadható az ÉrtSz. leírásának: „2.||a. (átv[itt értelemben]) Tényeknek, eseményeknek illúzióktól mentes, szigorú, rideg megítélése." A szótár Kaffka Margittól és Szabó Lőrinctől való szövegmetszeteiben keserü, illetőleg vigasztalan kontingencia mutatkozik. Balassi Bálint, Zrínyi Miklós, Csokonai és Arany János egyszer-egyszer használta a szót (BalassiSz., ZrínyiSz., CsokSzkt., AranySz.; Petőfi még egyszer sem). Az ő használatuk az alkoholmentességgel, a józansággal kapcsolatos, vagyis a szó nem a Radnóti-vershez idézett jelentésben van. A ritka előfordulásoknak nagy a hírértéke, így a Radnóti-adaténak is. Mellesleg megjegyzendő, hogy a józanság nincs a SzGySz.-ben sem, tehát a szépprózában sem a leggyakoribb szuperlexémák között. A $2 \times 2$ hírérték szempontjából ugyancsak magas szintű, tehát stiláris szempontból eleve hatásos a maga helyén, ehhez járul a számtani müvelet egyszerüségének nyilvánvalósága, vagyis a $2 \times 2$ kifejezés egyszersmind szimbolikus, jelentésének áttételességét a metaforába építése erősíti.

Néhány matematikai-algebrai jel is föl-fölbukkan szimbolikus utalásként a természet, a társadalom és a gondolkodás lehetőségei vagy éppen lehetetlenségei kapcsán a (gondolati) lírában.

A korunkbeli Tandori Dezső Nyitó $\infty$ és Záró $\infty$ című szonettekkel kezdi, illetőleg fejezi be egyik verses kötetét (Tandori 1976: 7, 218).

Karinthy Frigyes egyik Így írtok ti-darabjában éppenséggel az írás módszerének szélsőségét (alig lehetséges módját?) parafrazálja Babits Mihály $A$ Danaidák címü verse kapcsán. A Dana idák címú paródiájához a „Matematikai költemény” magyarázó megjegyzést fűzte, továbbá a négyzetre emelést („És mekegve és makog-

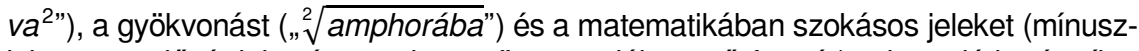
jelet, egyenlőségjelet és emeletes törtre emlékeztető formát) mint a látható stílus elemeit alkalmazza (Karinthy 1959: I, 24).

A gyökjelet és a mínuszjelet Weöres Sándor is alkalmazza: „Hajló terünkön kívül még hány világ van? | te titkod ez, $\sqrt{-x} \mid$ Ki rabként tengsz az anyagi világban, | Mint honát vesztett Vercingetorix” (Weöres 2013: 395). Másutt Weöres ezt a képletet (?) használja „A + A + Diff” (Weöres 2009-2013: III, 25). A költő fiatal korából tudni lehet, hogy nehezen boldogult az iskolák kötöttségeivel, ezzel összefüggésben a tanulásával sem mindig felelt a meg az általános követelményeknek, Id. Lőcsei Péter 2004. Az efféle helyzetből született a Diáknotesz című verse, amelyben többször ismétlődik a szinusztétellel kapcsolatos esete: „Én, végtelenben kréta-vándor, | nem találtam a befogókat... | Jaj, nem való e tábla-élet | végtelenben tapogatóknak, | nem megy a színusz-tétel, Sándor" (2009-2013: I, 28). Nincs tudomásom, hogy Weöres tanult-e, olvasott-e a permutációról, mindenesetre írt olyan müvet, amilyenben ennek lehetőségét használta föl: 


\section{Tenger felhő csillag szántás \\ csilger fellag szánhő tentás \\ lagten hőger szánfel csiltás \\ felcsil szánger hőten lagtás \\ hőszán tencsil lagger feltás \\ szánlag felcsil gerten hőtás \\ csilfel lag hő tenfel gertás}

A szöveg szótagjai mátrixokra bontva:

$\begin{array}{llllllll}\text { Ten } & \text { ger } & \text { fel } & \text { hó } & \text { csil } & \text { lag } & \text { szán tás } \\ \text { csil } & \text { ger } & \text { fel } & \text { lag } & \text { szán } & \text { hő } & \text { ten } & \text { tás } \\ \text { lag } & \text { ten } & \text { hó } & \text { ger } & \text { szán } & \text { fel } & \text { csil } & \text { tás } \\ \text { fel } & \text { csil } & \text { szán } & \text { ger } & \text { hő } & \text { ten } & \text { lag } & \text { tás } \\ \text { hó } & \text { szán } & \text { ten } & \text { csil } & \text { lag } & \text { ger } & \text { fel } & \text { tás } \\ \text { szán } & \text { lag } & \text { fel } & \text { csil } & \text { ger } & \text { ten } & \text { hó } & \text { tás } \\ \text { csil fel } & \text { lag } & \text { hö } & \text { ten } & \text { fel } & \text { ger } & \text { tás }\end{array}$

A vers négy szava nyolc szótagjának ismétlés nélküli faktoriálisa (8!) - nagy szómennyiséget eredményezne, 40.320 darabot! (A faktoriális jelét - ! - Christian Kramp vezette be 1808-ban.) A mátrix mutatja, hogy a költőnek nem ez volt a törekvése, hanem a tás elemmel az egyes sorokat (szövegmondategységeket) rendszeresen lezárja. Ez mutatja, hogy a művészi alkotásmódot nem befolyásolja a cserefolyamat rendszere $\left(P_{n}=n !\right)$, részletesen ld. Büky (2015).

A bemutatott szöveghelyeken íróik ugyanúgy használják a kifejezés, a stílushatás szempontjából a föntebb tárgyalt matematikához, algebrához, mértanhoz köthető fogalmak nyelvi anyagát, mint bármi más nyelvi lehetőséget.

P.S.

A fenti felhő színű csokorral köszönti hajdani egyetemi hallgatóját, később kollegináját és $A$ mai magyar nyelv leírásának újabb módszerei címü konferenciák és kiadványok szervező- és szerkesztőtársát a szerző.

\section{Hivatkozások}

Arany János 1966a. Hatvani. In Összes költeményei. Budapest: Magyar Helikon. 299-302.

Arany János 1966b. Az elveszett alkotmány. In Összes költeményei. Budapest: Magyar Helikon. 1295-1397.

Arany János 1966c. Bolond Istók. In Összes költeményei. Budapest: Magyar Helikon. 1536-1604.

AranySz. = Beke József 2018. Arany-szótár I-III. Arany János költói nyelvének szókészlete. Budapest: Anyanyelvápolók szövetsége - Inter.

BalassiSz. = Jakab László - Bölcskei András 2000. Balassi-szótár. Debrecen: Debreceni Egyetem BTK Magyar Nyelvtudományi Tanszék. 
Büky László 2015. „Tenger felhő csillag szántás” - A tekhné egy Weöres Sándorversben. Magyar Nyelv 111:68-74.

Csokonai Vitéz Mihály 1978. Az özvegy Karnyóné 's két szeleburdiak. In Öszes múvei. Színmúvek 2. Budapest: Akadémai Kiadó. 173-206.

Csokonai Vitéz Mihály 2002. Elöbeszéd [A' Tavaszhoz]. In Öszes múvei. Tanulmányok. Budapest: Akadémai Kiadó. 35-40.

CsokSzkt. = Jakab László - Bölcskei András 2017. Csokonai költeményeinek szótára I-II. Csokonai-szókincstár III. Debrecen: Debreceni Egyetemi Kiadó.

ÉrtSz. = Bárczi Géza - Országh László (főszerk.) 1959-1962. A magyar nyelv értelmező szótára I-VII. Budapest: Akadémiai Kiadó.

ISO 5776:2016. Graphic technology - Symbols for text proof correction.

Karinthy Frigyes 1959. Így írtok ti I-II. Budapest: Szépirodalmi Könyvkiadó.

Lőcsei Péter 2004. Weöres-mozaikok, III. Emlékek Weöres Sándor diákkoráról. http://www.vasiszemle.hu/2004/02/locsei.htm (2018. III. 3.)

Marno János 1999. Nincsen líra $\sqrt{ }$ nélkül. Budapest: Palatinus Könyvek Kft.

Móricz Zsigmond 1962. A fáklya. In Regényei és elbeszélései 2. Budapest: Magyar Helikon. 135-372.

MSZ 3491-1988. Magyar Népköztársaság Országos Szabvány. Korrektúrajelek és alkalmazásuk. Budapest: Magyar Szabványügyi Hivatal, 1989. június 1. $1-14$.

Nszt. = Ittzés Nóra (főszerk.) 2006-. A magyar nyelv nagyszótára. Budapest: MTA Nyelvtudományi Intézet.

Radnóti Miklós 1959. Levél a hitveshez. In Összes versei és müfordításai. Budapest: Szépirodalmi Könyvkiadó. 262-263.

RadnótiSz. = Beke József 2009. Radnóti-szótár. Radnóti Miklós költói nyelvének szókészlete. Budapest: Argumentum.

SzGySz. = Füredi Mihály - Kelemen József (szerk.) 1989. $A$ mai magyar nyelv szépprózai gyakorisági szótára 1965-1977. Budapest: Akadémiai Kiadó.

Tandori Dezső 1976. A mennyezet és a padló. Budapest: Magvető Könyvkiadó.

Timkó György (szerk.) 1972: Helyesírási és tipográfiai tanácsadó. Budapest: Nyomdaipari Egyesülés.

Trócsányi Zoltán 1918. X ut tök. In A Magyar Nyelv dolgozótársai: Emlék Szily Kálmánnak. Budapest: Hornyánszky Viktor Cs. Kir. Udvari Könyvnyomdája. 87-89.

Weöres Sándor 2013. [Ami az Orbis pictusból kimaradt]. In Elhagyott versek. Budapest: Helikon. 389-395.

Weöres Sándor 2009-2013. Egybegyújtött költemények I-III. Budapest: Helikon. 27-33.

ZrínyiSz. = Beke József 2004. Zrínyi Miklós életmúvének szókészlete. Budapest: Argumentum.

\section{A szerzőről}

Büky László nyelvész (SZTE), az MTA doktora. Főbb kutatási területei: nyelvtörténet, stilisztika, szövegnyelvészet. Legutóbbi könyve: Versek, szavak, szerkezetek Weöres Sándor lírájában. Magyar Szemiotikai Társaság, Budapest, 2019.

Elérhetősége: buky@hung.u-szeged.hu 